\title{
Economic feasibility of a complete diet industrial production project for horses
}

\section{Viabilidade econômica do projeto de produção industrial de dietas completas para equinos}

\author{
Kátia Feltre $^{1} \mathbb{D}$; Augusto Hauber Gameiro ${ }^{1}$; Alexandre Augusto de Oliveira Gobesso ${ }^{1}$ \\ ${ }^{1}$ Universidade de São Paulo, Faculdade de Medicina Veterinária e Zootecnia, Departamento de Nutrição e Produção Animal, \\ Pirassununga - SP, Brazil
}

\begin{abstract}
This study evaluated the economic viability of industrial production of complete diets for equine species, using three sources of fiber (dehydrated whole corn plant, dehydrated elephant grass, or Tifton 85 hay) submitted to two types of thermal processing (pelleting or extrusion). A survey and elaboration of costs from the agricultural production of roughage to the commercialization of the final product was conducted. Three scenarios were compared: $S 1$ - basal price of complete diet (ingredients supplied together, but purchased separately); S2 - price of S1 plus 10\%; S3 - price of $S 1$ plus $20 \%$. Profitability indicators applied were internal rate of return (IRR) and net present value (NPV). Simple payback was used to verify return on investment time. Sensitivity analysis was performed to identify the items that most influence the economic results. Simple payback ranged from one to six years. The highest values of IRR $(>100 \%$ per year) and NPV were obtained for the extruded diets in scenario 3. Only the pelletized diet containing Tifton 85 hay in scenario 1 was not economically feasible, presenting negative IRR. The inputs make up the item with the greatest burden on the production process (mean 89\%). Except for pelletized diet containing Tifton 85 hay in scenario 1, the other projects present IRR above the minimum attractiveness rate (MAR) and were considered economically feasible. Keywords: Horses feeding. Economic analysis. Roughage. Thermal processing.
\end{abstract}

\section{RESUMO}

O presente trabalho avaliou a viabilidade econômica do projeto de produção industrial de dietas completas para a espécie equina, utilizando três fontes de fibra (rolão de milho ou capim elefante desidratado ou feno de Tifton 85) submetidas a dois tipos de tratamento térmico (peletização ou extrusão). Foram realizados o levantamento e elaboração de custos desde a produção agrícola do volumoso até a comercialização do produto final. Foram propostos três cenários comparativos: $S 1$ - preço base da dieta completa (ingredientes fornecidos ao mesmo tempo, porém, separadamente); S2 - preço de S1 mais 10\%; S3 - preço de S1 mais 20\%. A Taxa Interna de Retorno (TIR) e o Valor Presente Líquido (VPL) foram os indicadores de rentabilidade. O Payback simples foi utilizado para verificar o tempo de retorno do investimento. Foi realizada análise de sensibilidade para identificar os itens que mais influenciaram os resultados econômicos. O Payback simples variou de um a seis anos. Os maiores valores de TIR (>100\% a.a) e VPL foram obtidos para as dietas extrusadas no cenário 3. Apenas a dieta peletizada contendo feno de Tifton 85 no cenário 1 não foi viável economicamente, apresentando TIR negativa. Os insumos compõem o item de maior oneração no processo produtivo (média de 89\%). Exceto para dieta peletizada contendo feno de Tifton 85 no cenário 1, os demais projetos apresentam TIR acima da taxa média de atratividade sendo considerados viáveis economicamente.

Palavras-chave: Ração para cavalos. Análise econômica. Forragem. Processamento térmico. 
Correspondence to:

Kátia Feltre

Universidade de São Paulo, Faculdade de Medicina Veterinária e Zootecnia, Departamento de Nutrição e Produção Animal

Av. Duque de Caxias Norte, 225

CEP: 13635-000, Pirassununga - SP, Brazil

e-mail: katiafeltre@yahoo.com.br

Received: May 22, 2019

Approved: January 27, 2020

How to cite: Feltre K, Gameiro AH, Gobesso AAO. Economic feasibility of a complete diet industrial production project for horses. Braz J Vet Res Anim Sci. 2019;56(4): e158212. https://doi.org/10.11606/issn.1678-4456.bjvras.2019.158212.

\section{Introduction}

There are an estimated 5 million horse heads in Brazil, with 1.1 million destined for sport, recreation and breeding and 3.9 million intended to work. However this number is still not well defined since it does not consider the actual number in urban establishments and/or where the breeders themselves often omit information for reasons of secrecy (Lima \& Cintra, 2016).

Regarding the expressiveness of the horse feed market, according to data from the companies associated with Sindirações (2016), about 66.5 million tons were produced in 2015 and $1 \%$ of the production went to equines. However according to the Ministry of Agriculture, Livestock, and Supply, considering the other companies registered, it is estimated that this market is $60 \%$ higher (Lima \& Cintra, 2016).

In horse breeding, hay wastage when it is supplied in bays or the field, and the generation of dust resulting from the handling of this material, are unfavorable points of horse production, and targets of research for the economics of property. McMillan et al. (2009) and Martinson et al. (2012) have shown that hay waste both in the field and within the bays can vary from 1.3 to $57 \%$, representing significant economic losses.

In addition, difficulties in assessing roughage quality are also relevant issues in property economics. In battalions of military police or urban breeders, lack of guidance and use of low-quality forages negatively influence the digestive health of animals with reduced performance during work, increase costs for veterinary treatments, and increase risk of death.

Several researchers analyzed the possibility of adequately and safely replacing traditional feeding with a single processed complete diet. This strategy smoothes the production barriers, while economically enabling production without compromising the requirements of each animal category or changing behavioral parameters (Elia et al., 2010; Feltre et al., 2016; Manzano, 1987). However, lack of knowledge about the effects of this diet on the digestive physiology of the horses and the technologies for producing these foods postponed their presence in the market.

The objective of the present study was to evaluate the economic feasibility of the single complete diet industrial production project with the use of three different sources of fiber (dehydrated elephant grass, dehydrated whole corn plant, or Tifton 85 hay), submitted to two thermal processing (pelleting and extrusion) for the equine species.

\section{Material and Methods}

The economic feasibility analysis of the complete pelletized and extruded diet was developed at Pirassununga (São Paulo, Brazil; $21^{\circ} 57^{\prime} 27.9^{\prime \prime} \mathrm{S} 47^{\circ} 27^{\prime} 10.0^{\prime \prime} \mathrm{W}$ ), through a detailed survey and elaboration of costs in electronic spreadsheets. Research on animals was conducted according to the Institutional Animal Care and Use Committee (protocol $\mathrm{n}^{\circ}$ 610004; CEUA/FMVZ/USP).

The method used followed the same precepts of Feltre et al. (2016). For this simulation, the hypothesis that all production would be commercialized was considered; therefore, no idleness in the system. For the development of the study, a rural property located in the city of Londrina (PR, Brazil) was identified as a reference. Method of cost accounting, both agricultural and industrial, followed that proposed by Martins (1990). All prices of inputs and services by the market were assessed through telephone calls, internet searches or visits to establishments.

The diets evaluated were divided into complete diet pelletized or extruded composed of $50 \%$ of roughage (dehydrated whole corn plant, dehydrated elephant grass, or Tifton 85 hay) added with concentrate totaling six types of diets, each formulated to present the same nutritional value. The daily dry matter intake adopted for the economic analysis was $2 \%$ of body weight, considering the average weight of the animals in maintenance of $450 \mathrm{~kg}$, following the recommendations of the Nutrient Requirements of Horses (National Research Council, 2007).

To simulate sales volume, we considered a captive market referring to the consumption of the complete diet exclusively for 2,250 and 3,215 animals in maintenance, per year, for the pelletized and extruded product, respectively. These values were calculated according to the annual consumption of the animals in maintenance, as cited above, in relation to the annual production capacity of the pelletizer $\left(3.5 t\right.$ hour $\left.^{-1}\right)$ 
and extruded (5.0 thour ${ }^{-1}$ ) products, respectively. Also we considered that commercial distribution of the product would be carried out by a representative, who would receive a gross margin of $20 \%$.

The equipment and procedures used were: 1) adapted biomass pelletizer (Eng-Maq, model: Eng 0200V, flat die of $15 \mathrm{~mm}$ diameter). The process temperature of raw material was $80-95^{\circ} \mathrm{C}$, inlet moisture around $2 \%$ and outlet $15 \%$, cooling-in time of $5 \mathrm{~min}$ under non-vented air ventilation; 2) adapted extruder (self-fabricated, die of $10 \mathrm{~mm}$ diameter). The process temperature of raw material was $90^{\circ} \mathrm{C}$ to $120^{\circ} \mathrm{C}$, inlet moisture of $21 \%$ and outlet $16 \%$ and a cooling-in time of 5 min under non-vented air ventilation.

Regarding cost of agricultural inputs, the production of dry matter for each fiber source was considered according to data obtained in the literature (Flores et al., 2012; Pizzani et al., 2012; Zopollatto et al., 2009). Production costs were assessed for each crop (dehydrated whole corn plant, dehydrated elephant grass, and Tifton 85 hay). The expenses of the industrial inputs included the specific equipment (pelletizer and extruder), quantity and proportion of the ingredients required for each diet, electric energy costs of the region in 2016 (COPEL; Paraná, Brazil) and costs of packaging and respective identifications.

Transportation costs were updated according to ESALQ-LOG ${ }^{1}$ considering the expenses of the company (salary and working hours of the driver), operating and market costs (referring to the acquisition of the set and maintenance of the truck) and a $300 \mathrm{~km}$ radius of distribution of the goods. The commercialization product analysis was carried out according to Feltre et al. (2016).

Regulations involved in feed production and commercialization of the product were obtained from the database of the Official Gazette; for taxes, the rate of $23.93 \%$ per month of revenues was considered assuming presumed profit, according to information provided by an accounting firm.

The economic parameters evaluated were: fixed assets (realty, machinery, equipment and furniture), inputs (agricultural and industrial), personnel expenses (operating and administrative), production indicators (quantity in tons and price), nutritional equivalence of complete diet (dehydrated whole corn plant, dehydrated elephant grass, or Tifton 85 hay), taxation (municipal, state and federal) and transportation (to the consumer market). With these parameters, the income statement (monthly) and cash flow (annual, for 30 years) were prepared.
Three scenarios were proposed for the three fiber sources and the two thermal processing types based on differentiated selling prices from complete diet to the final consumer (horse breeder). For the project to be viable the selling price of the complete diet to the consumer must be equivalent to the price of the standard horse diet. To estimate the base selling price (scenario $1, S 1$ ) the quantity and price of the commercial concentrate, hay and mineral salt used for a horse's daily feed were considered. The value found was $\mathrm{R} \$ 1.42 / \mathrm{kg}$ ( $\mathrm{R} \$ 12.80$ for an animal consuming $9 \mathrm{~kg}$ of diet per day), already including the gross margin of $20 \%$ of the distributor. To verify changes in income and cash flow, price simulations were performed considering an increase of $10 \%$ (scenario 2, S2; R \$ 1.56/kg) and of 20\% (scenario 3, S3; R\$ $1,69 / \mathrm{kg}$ ) in relation to $\mathrm{S} 1$ for the three fiber sources.

In the cash flow spreadsheet, income and expenses were estimated over the 30 -year project horizon. In this investment, the discount rate $r$ (considered as the minimum attractiveness rate; MAR) of $7.20 \%$ per year, was obtained from the nominal average daily rate of interest (SELIC, $2016^{2}$ ) from January to December 2016, and by the inflation rate represented by the National Consumer Price Index (INPC/IBGE) accumulated until November 2016 according to Equation 1:

$\mathrm{r}=\left[\frac{(1+\mathrm{j})}{(1+\mathrm{in})}\right]-1$

Where $r=$ real interest rate; $j=$ nominal interest rate; in $=$ inflation rate.

To evaluate the feasibility of the production of the complete diet, the following financial profitability indicators were used: Net present value (NPV) and internal rate of return (IRR). Simple payback was used to verify the time needed to recover the initial investment. Investment with IRR greater than or equal to the discount rate (or MAR), and NPV greater than zero was considered economically viable.

The NPV of a cash flow is equal to the present value of the sum of the net cash flows forecast for the project horizon, calculated as (Equation 2):

$$
\mathrm{NPV}=\sum_{\mathrm{t}=1}^{\mathrm{n}} \frac{\mathrm{R}_{\mathrm{t}}}{(1+\mathrm{i})^{\mathrm{t}}}
$$

$\mathrm{R}_{\mathrm{t}}=$ net cash flow at the time cash flow occurred $(\mathrm{t}) ; \mathrm{i}=$ real interest rate (\%); $\mathrm{n}=$ period of time. The IRR, in turn, is the discount rate capable of zeroing the NPV. This rate is obtained through computational simulation.

\footnotetext{
http://www.bcb.gov.br/?SELICDIARIOS
} 
A sensitivity analysis was performed to identify elements that may affect the economic results of a system and influence the financial viability of the activity. By computer program, the results are obtained from the introduction of the values of the parameters in the expression, the simulation is carried out and it is then verified as to how and in what proportions these variables affect the final results of the project (Lima et al., 2007).

The influence of the change of a variable on the results of the system was determined by evaluating a more rigorous interpretation, which generates a more precise interpretation of the risks associated with the activity (Jerônimo, 2013). Based on this information, investors will know if future variations in the diet will lead to economic losses or gains. For this study, we took as an indicator the services/product costs sold for the pelletized and extruded products in scenario 1 , since the other scenarios follow the same pattern of results.

\section{Results and Discussion}

This work evaluated the economic viability of producing complete diets for horses. However, providing a quality product at market-compatible prices is required. Table 1 shows results of the analysis of the economic and productive feasibility of the complete diet. It is possible to infer that, except for the pelletized complete diet composed of Tifton 85 hay and commercialized in scenario 1 , the production of the other diets were economically viable, presenting IRR above the MAR of $7.20 \%$ per year. The simple payback ranged from 1 to 6 years, and the highest IRRs were obtained with the extruded complete diet marketed in scenario 3.

When the respective scenarios, within each processing, are evaluated for the average monthly net profit (AMNP, $\mathrm{R} \$$ /month) and IIR, the pelletized products always have lower values about the extruded product. This result is related to the productivity of each equipment evaluated in this study, which for the pelletizer was $3.5 \mathrm{thour}^{-1}$ and the extruder, 5.0 t hour $^{-1}$.

When the respective scenarios are compared regarding source of fiber used, the diets containing Tifton 85 hay presented the lower value of AMNP, whereas the diets containing dehydrated whole corn plant presented the highest values. These results were influenced by the number of cuts during the year ( 2 and 5 cuts for dehydrated whole corn plant and Tifton 85 hay, respectively) and by the higher dry matter yield $\left(24 \mathrm{t}_{\text {year }}{ }^{-1}\right)$ of the Tifton 85 hay $\left(13 \mathrm{t} \mathrm{year}^{-1}\right)$ considered for this study.

Tifton 85 hay is a grass widely used in hay production and equine nutrition, but the maximum productive expression depends directly on soil management during the planting phase, the cuts, and strict nitrogen fertilization. Also cut management is essential to ensure adequate regrowth (Taffarel et al., 2014). With this, it is possible to increase the productivity of this species with appropriate management practices with consequent improvement of the economic results of the project.

When we evaluated the diet composed of Tifton 85 hay pelletized in scenario 1 , where the price of the complete diet to the consumer is $\mathrm{R} \$ 1.42 / \mathrm{kg}$, we found that the IRR and AMNP were negative. However, when the price of complete diet increased by $10 \%$ of the base value (scenario 2), i.e., $\mathrm{R} \$ 1.56 / \mathrm{kg}$, the results were positive (IRR of $38.04 \%$ per year and AMNP of R $\$ 36,129.32 /$ month). It is thus possible to infer that, despite the low productivity considered in this project, the increase of $10 \%$ in the base value is enough to make the project viable.

Analyzing scenario 3, where the price of complete diet to the consumer is $\mathrm{R} \$ 1.69$ per kilo, the extruded diet with dehydrated whole corn plant had the highest AMNP ( $\mathrm{R} \$ 214,603.12 /$ month), followed by the extruded diet containing dehydrated elephant grass (R $\$ 189,661.89 /$ month) and extruded Tifton 85 hay (R\$152,390.15/month). In addition to the productivity of the equipment and dry mass of forages, the lower number of cuts per year in the case of maize may have interfered with the results, reducing direct annual costs of agricultural inputs.

This project shows the flexibility of using different fiber sources in the manufacture of equine diets to reduce production costs without affecting quality of the final product. Elephant grass has high productive potential and adequate nutritional value and can offer around five cuts in the year, and its use in feeding horses is recommended in periods of feed scarcity. However, attention to soil and plant fertility management is indispensable because it presents rapid growth, decreasing the nutritive value with the advancement of maturity (Lima et al., 2010).

The dehydrated whole corn plant as an alternative feed in equine production is still little studied. Thus, processing of dehydrated whole corn plant, besides presenting potential to provide a fibrous feed and, to be used by horses and other non-ruminant herbivores, can be a way of reducing input costs (Goes et al., 2013). However, Tifton 85 hay, widely used in horse feeding due to the greater preference by this species (Dittrich et al., 2007), is provided both in the conserved form (hay) and pasture. However, dry matter yield for elephant grass and dehydrated whole corn plant is lower (Azar et al., 2009; Pizzani et al., 2012). 
Table 1 - Results of the economic feasibility analysis of complete diet production for horses. Evaluation of three possible marketing scenarios (S). Pirassununga, 2016

\begin{tabular}{|c|c|c|c|c|c|c|}
\hline \multirow{2}{*}{ Indicator } & \multicolumn{3}{|c|}{ Pelletized Tifton 85 hay } & \multicolumn{3}{|c|}{ Extruded Tifton 85 hay } \\
\hline & $S 1^{(1)}$ & $S 2^{(2)}$ & $\mathbf{S 3}^{(3)}$ & S1 & S2 & S3 \\
\hline Investment (R\$) & $1,871,764.76$ & $1,871,764.76$ & $1,871,764.76$ & $2,153,337.03$ & $2,153,337.03$ & $2,153,337.03$ \\
\hline Complete diet selling price $(\mathrm{R} \$ / \mathrm{kg})$ & 1.11 & 1.22 & 1.33 & 1.11 & 1.22 & 1.33 \\
\hline Complete diet price to the farmer $(\mathrm{R} \$ / \mathrm{kg})$ & 1.42 & 1.56 & 1.69 & 1.42 & 1.56 & 1.69 \\
\hline Cultivated area required (ha) & 284 & 284 & 284 & 406 & 406 & 406 \\
\hline Gross revenue (R\$/month) & $680,680.00$ & $751,520.00$ & $819,280.00$ & $972,400.00$ & $1,073,000.00$ & $1,170,400.00$ \\
\hline Costs of services/products sold (R\$/month) & $522,952.33$ & $522,952.33$ & $522,952.33$ & $725,111.65$ & $725,111.65$ & $725,111.65$ \\
\hline Average monthly net income ( $\mathrm{R} \$$ /month) & $-17,758.66$ & $36,129.32$ & $87,674.36$ & $1,771.55$ & $70,208.36$ & $84,548.86$ \\
\hline Internal Rate of Return (\%per year) & -12.99 & 38.04 & 72.53 & 12.24 & 114.49 & 161.88 \\
\hline Simple Payback (year) & - & 3 & 2 & 6 & 1 & 1 \\
\hline \multirow[t]{2}{*}{ Net Present Value (R\$) } & $-2,159,338.59$ & $5,628,563.71$ & $13,077,861.55$ & $886,023.47$ & $26,799,435.80$ & $39,064,078.19$ \\
\hline & \multicolumn{3}{|c|}{ Pelletized dehydrated elephant grass } & \multicolumn{3}{|c|}{ Extruded dehydrated elephant grass } \\
\hline Investment (R\$) & $1,619,996.37$ & $1,619,996.37$ & $1,619,996.37$ & $1,793,667.90$ & $1,793,667.90$ & $1,793,667.90$ \\
\hline Complete diet selling & 1.11 & 1.22 & 1.33 & 1.11 & 1.22 & 1.33 \\
\hline Complete diet price to the farmer $(\mathrm{R} \$ / \mathrm{kg})$ & 1.42 & 1.56 & 1.69 & 1.42 & 1.56 & 1.69 \\
\hline Cultivated area required (ha) & 106 & 106 & 106 & 151 & 151 & 151 \\
\hline Gross revenue (R\$/month) & $680,680.00$ & $751,520.00$ & $819,280.00$ & $972,400.00$ & $1,073,600.00$ & $1,170,400.00$ \\
\hline Costs of servi & $496,862.11$ & $496,862.11$ & $496,862.11$ & $687,839.91$ & $687,839.91$ & $687,839.91$ \\
\hline Average monthly net income ( $\mathrm{R} \$$ /month) & $8,331.56$ & $62,219.55$ & $113,764.58$ & $39,043.29$ & $116,026.13$ & $189,661.89$ \\
\hline Internal Rate of Return (\%per year) & 17.05 & 61.03 & 99.70 & 40.63 & 93.53 & 142.95 \\
\hline Simple Payback (year) & 5 & 2 & 2 & 3 & 2 & 1 \\
\hline \multirow[t]{2}{*}{ Net Present Value (R\$) } & $1,367,221.45$ & $9,155,123.74$ & $16,604,421.59$ & $5,923,966.38$ & $17,049,541.09$ & $27,691,395.16$ \\
\hline & \multicolumn{3}{|c|}{ Pelletized dehydrated whole corn plant } & \multicolumn{3}{|c|}{ Extruded dehydrated whole corn plant } \\
\hline Investment (R\$) & $2,037,463.85$ & $2,037,463.85$ & $2,037,463.85$ & $2,196,195.25$ & $2,196,195.25$ & $2,196,195.25$ \\
\hline Complete diet selling $\mathrm{F}$ & 1.11 & 1.22 & 1.33 & 1.11 & 1.22 & 1.33 \\
\hline Complete diet price to the farmer $(\mathrm{R} \$ / \mathrm{kg})$ & 1.42 & 1.56 & 1.69 & 1.42 & 1.56 & 1.69 \\
\hline Cultivated area required (ha) & 154 & 154 & 154 & 220 & 220 & 220 \\
\hline Gross revenue (R\$/month) & $680,680.00$ & $751,520.00$ & $819,280.00$ & $972,400.00$ & $1,073,600.00$ & $1,170,400.00$ \\
\hline Costs of services/products sold (R\$/month) & $479,008.25$ & $479,008.25$ & $479,008.25$ & $660,389.68$ & $660,389.68$ & $660,389.68$ \\
\hline Average monthly net income ( $\mathrm{R} \$$ /month) & $23,676.42$ & $77,564.41$ & $129,109.44$ & $63,984.52$ & $140,967.36$ & $214,603.12$ \\
\hline Internal Rate of Return (\%per year) & 26.88 & 60.93 & 91.74 & 50.23 & 93.16 & 133.55 \\
\hline Simple Payback (year) & 4 & 2 & 2 & 2 & 2 & 1 \\
\hline
\end{tabular}

Net Present Value (R\$)

$\begin{array}{llllll}3,699,486.90 & 11,487,389.20 & 18,936,687.05 & 9,642,253.09 & 20,767,827.80 & 31,409,681.87\end{array}$

Footnotes: ${ }^{(1)}$ Price of complete diet equivalent to a traditional diet which uses ingredients supplied together, but purchased separately; ${ }^{(2)} \mathrm{Considering} \mathrm{a} \mathrm{value} 10 \%$ higher in relation to $\mathrm{S} 1 ;{ }^{(3)}$ Considering a value $20 \%$ higher than $\mathrm{S} 1$.

Figure 1 displays the results of the sensitivity analysis, taking as an indicator the services/product costs sold for the pelletized and extruded products in scenario 1 , since the other scenarios follow the same pattern of results. For this analysis, the items that make up the cash flows of each system were studied individually, wherein we selected one parameter and observed its effect on viability indicators. By computer program, we obtained the results from the introduction of the values of the parameters in the expression, carried out the simulation and then verified how and in what proportions these variables affected the final results of the project (Lima et al., 2007).

The cost structure of the evaluated products was similar. The inputs directly influence the project budget, representing, on average, $89 \%$ of the costs and occupying the first place in the sensitivity analysis, followed by the personal items (averaging 3.9\%), land lease (averaging 3.3\%), depreciation (with an average of $2.3 \%$ ), general operating expenses (average of $1.3 \%$ ) and maintenance (average of $0.4 \%$ ). For this project, the "inputs" category included agricultural inputs (soil correction, planting and maintenance fertilizer, herbicides, insecticides and soil prepare) and industrial inputs (diet formulation, energy and packaging). Thus, the use of alternatives that can reduce inputs costs without changing feed quality is necessary for better performance and profitability of the company.

Feltre et al. (2016) evaluated the economic feasibility of extruded enriched hay produced with $40 \%$ hay and $60 \%$ concentrate and obtained IRR ranging from 9.44 to $66.3 \%$ per year, and investment payback time of 11 to 2 years, when evaluated in two scenarios similar to the present work. The authors considered the economically feasible investment to be promising from the nutritional, logistic and economic point of view. 
Pelletized Tifton 85 hay

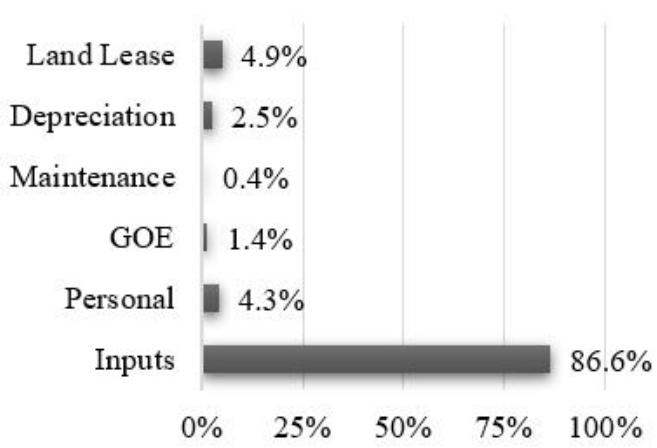

Pelletized dehydrated elephant-grass

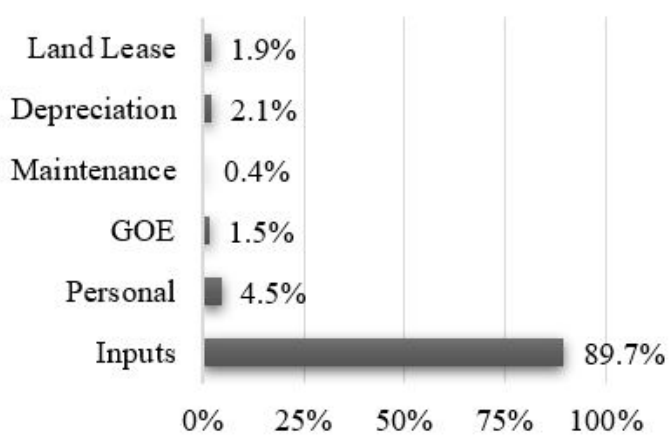

Pelletized Whole Corn Plant

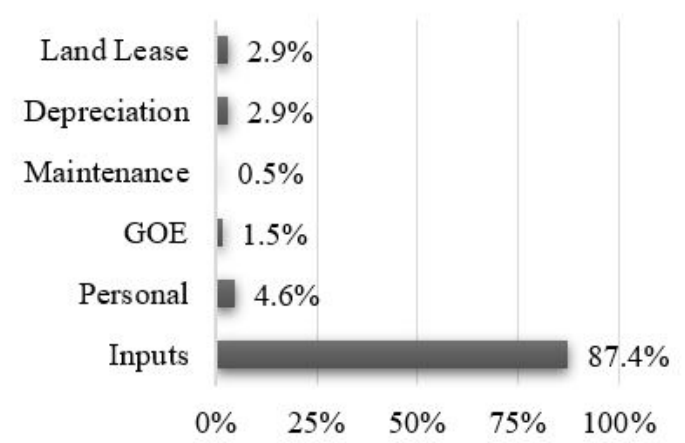

Extruded Tifton 85 hay

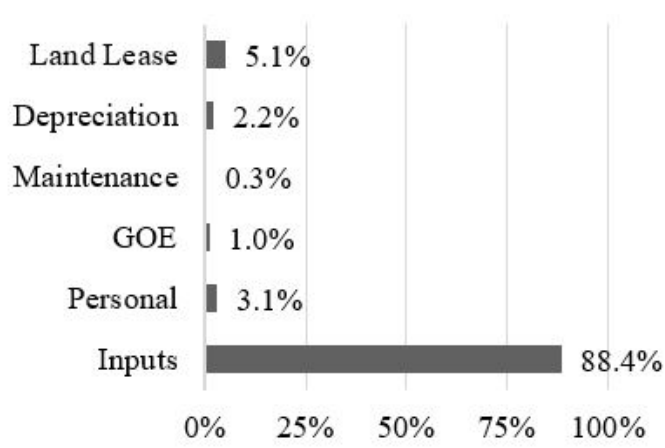

Extruded dehydrated elephant-grass

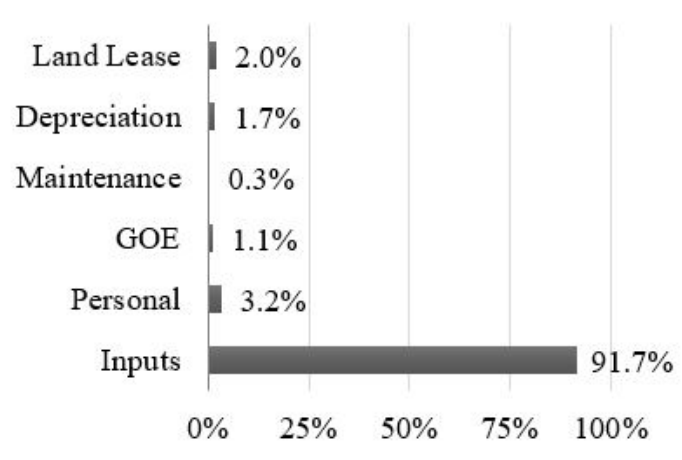

Extruded Whole Corn Plant

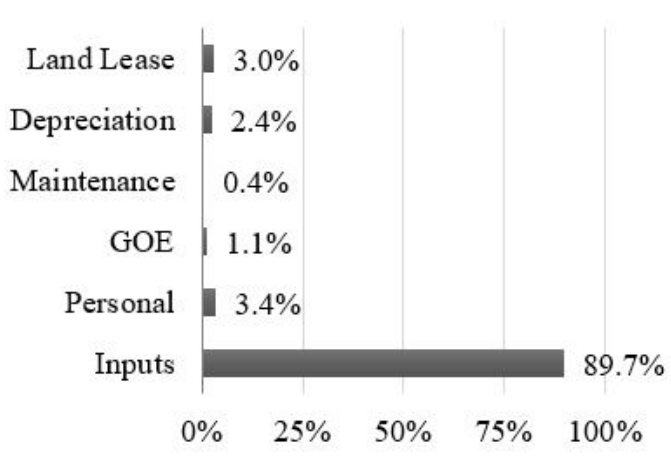

Figure 1. Sensitivity analysis: influence of the items that make up "Costs of Services/Products Sold" on the economic analysis of complete horse diets in scenario 1. GOE = General Operating Expenses.

\section{Conclusions}

Considering that a system is feasible when its IRR is equal to or greater than the opportunity cost of capital and, observing the three scenarios evaluated, it is possible to infer that the enterprise is economically feasible. In this context, the project would cover both initial investment and minimum remuneration required by the investor, generating a greater financial surplus in scenario 3 . Also the extruded diet produced with dehydrated whole corn plant showed a higher average monthly net profit than the other diets, as opposed to the pelletized complete diet composed for Tifton 85 hay in scenario 1 which showed no project feasibility.

\section{Conflict of Interest}

None

\section{Ethics Statement}

Institutional Animal Care and Use Committee (protocol $n^{\circ}$ 610004; CEUA/FMVZ/USP)

\section{Acknowledgements}

The authors would like to thank the company Nutriltex Indústria Zootécnia do Brasil Ltda for the financial assistance provided to this project. 


\section{References}

Azar GS, Nascimento MPSCB, Nascimento HTS, Oliveira ME, Carvalho MSS. Rendimento forrageiro e características morfológicas de Cynodon nos períodos chuvoso e seco. Rev Bras Saúde Prod Anim. 2009;11(2):133-43. http://dx.doi. org/10.15528/628.

Dittrich JR, Carvalho PCF, Moraes A, Oliveira EB, Dittrich RL, Oikawa M, Souza FTV, Santos F. Comportamento ingestivo de equinos em pastejo sobre diferentes dosséis. Cienc Anim Bras. 2007;8(1):87-94.

Elia JB, Erb HN, Houpt KA. Motivation for hay: effects of a pelleted diet on behavior and physiology of horses. Physiol Behav. 2010;101(5):623-7. http://dx.doi.org/10.1016/j. physbeh.2010.09.010. PMid:20869976.

Feltre K, Palagi MAF, Gameiro AH, Wajnsztejn H, Gobesso AAO. Economic feasibility of hay enriched extruded production as a complete diet for equine. Braz J Vet Res Anim Sci. 2016;53(1):55-9. http://dx.doi.org/10.11606/issn.1678-4456. v53ilp55-59.

Flores RA, Urquiaga S, Alves BJR, Collier LS, Boddey RM. Yield and quality of elephant grass biomass produced in the cerrados region for bioenergy. Eng Agric. 2012;32(5):831-9. http://dx.doi.org/10.1590/S0100-69162012000500003.

Goes RHTB, Silva LHX, Souza KA. Alimentos e alimentação animal [Internet]. Dourados: Editora UFGD; 2013 [cited 2015 July 28]. 80 p. Available from: http://www.ufgd.edu.br/editora/ cadernos-academicos/alimentos-e-alimentacao-animal/at_ download/pdflivro

Jerônimo CEM. Estudo de Viabilidade Econômica aplicado a um projeto agroindustrial: análise de sensibilidade. Rev Adm Roraima. 2013;3(2):156-80. http://dx.doi.org/10.18227/ rarr.v3i2.790.

Lima ES, Silva JFC, Vásquez HM, Araújo SAC, Lista FN, Costa DPB. Produção de matéria seca e proteína bruta e relação folha/colmo de genótipos de capim-elefante aos 56 dias de rebrota. R Bras Zootec. 2007;36(5):1518-1523. http://dx.doi. org/10.1590/S1516-35982007000700009

Lima ES, Silva JFC, Vásquez HM, Andrade EM, Deminicis BB, Morais JPG, Costa DPB, Araújo SAC. Agronomic and nutritional characteristics of the main varieties of elephant grass. Vet Zootec. 2010;17(3):324-34.

Lima RAS, Cintra AG. Revisão do estudo do Complexo do Agronegócio do Cavalo [Internet]. Brasília: MAPA; 2016 [cited 2019 May 5]. 54 p. Available from: http://www.agricultura. gov.br/assuntos/camaras-setoriais-tematicas/documentos/ camaras-setoriais/equideocultura/anos-anteriores/revisaodo-estudo-do-complexo-do-agronegocio-do-cavalo
Manzano A. Resultados de pesquisa em alimentação com equinos da raça árabe na UEPAE de São Carlos [Internet]. São Carlos: EMBRAPA; 1987 [cited 2015 July 28]. Avaliable from: https://ainfo.cnptia.embrapa.br/digital/bitstream/ CPPSE/10499/1/PROCIComT2AM1987.00049.pdf

Martins E. Contabilidade de custos. 4th ed. São Paulo: Atlas; $1990.311 \mathrm{p}$.

Martinson K, Wilson J, Cleary K, Lazarus W, Thomas W, Hathaway M. Round-bale feeder design affects hay waste and economics during horse feeding. J Anim Sci. 2012;90(3):104755. http://dx.doi.org/10.2527/jas.2011-4087. PMid:21984721.

McMillan ML, Wilson KR, Golden WC, Rakowitz LA. Influence of hay ring presence on waste in horses fed hay. Tex J Agric Nat Resour. 2009;22:69-73.

NRC: National Research Council. Nutrient Requirements of Horses. 6th ed. Washington, D.C.: National Academies Press; 2007. 360 p. https://doi.org/10.17226/11653

Pizzani R, Schaefer PE, Lovato T, Ludwig RL, Goulart RZ. Acúmulo de massa de forragem e parâmetros nutricionais do amendoim forrageiro e Tifton 85 em cultivo singular ou consórcio submetido ou não à adubação mineral. Enciclopédia Biosfera. Centro Científico Conhecer. 2012;8(14):23-32.

Sindirações. Boletim informativo do setor [Internet]. 2016 May [cited 2017 Jan 15]. Available from: http://sindiracoes. org.br/produtos-e-servicos/boletim-informativo-do-setor/

Taffarel LE, Mesquita EE, Castagnara DD, Oliveira PSR, Oliveira NTE, Galbeiro S, Costa PB. Produção de matéria seca e valor nutritivo do feno do tifton 85 adubado com nitrogênio e colhido com 35 dias. Rev Bras Saúde Prod Anim. 2014;15(3):544-60. http://dx.doi.org/10.1590/S1519-99402014000300003.

Zopollatto M, Nussio LG, Paziani SF, Ribeiro JL, Sarturi JO, Mourão GB. Relações biométricas entre o estádio de maturação e a produtividade de híbridos de milho para produção de silagem. Rev Bras Zootec. 2009;38(2):256-64. http://dx.doi. org/10.1590/S1516-35982009000200006.

Financial Support: Nutriltex - Indústria Zootécnia do Brasil Ltda. CNPJ: 12967142/0001-01.

Authors Contributions: Kátia Feltre participated in the planning, execution and confection of the manuscript. Alexandre Augusto de Oliveira Gobesso participated in the planning and confection of the manuscript. Augusto Hauber Gameiro participated in the economic analysis and confection of the manuscript. 